\title{
Bezpieczeństwo żywnościowe a ograniczenia w nabywaniu nieruchomości rolnych w kontekście strategii „Od pola do stołu”
}

\section{Wprowadzenie}

Pandemia COVID-19 uwidoczniła znaczenie, jakie dla funkcjonowania europejskich społeczeństw ma bezpieczeństwo żywnościowe. Załamanie dostaw żywności, a nawet sama możliwość załamania czy choćby ich ograniczenia, może w krótkim czasie doprowadzić do realnego zagrożenia bezpieczeństwa publicznego. W tym kontekście niezwykle ważna wydaje się rola państwa i Unii Europejskiej w zapewnieniu bezpieczeństwa żywnościowego.

Według danych publikowanych przez agendy ONZ na świecie następuje ciągły wzrost głodu od 2014 r., a tendencja ta nasila się w związku $\mathrm{z}$ pandemią COVID-19 ${ }^{1}$. W dokumentach tych zwraca się uwagę nie tylko na problem głodu, rozumianego jako brak dostępu do żywności, co dotyka głównie państw Afryki i zachodniej Azji, ale także na problem niewłaściwej diety wśród obywateli Unii Europejskiej, co pociąga za sobą poważne koszty społeczne i środowiskowe ${ }^{2}$. Jak się szacuje, zmiana diety może doprowadzić do ograniczenia emisji gazów cieplarnianych, a jednocześnie do zmniejszenia ukrytych kosztów zdrowotnych ${ }^{3}$. Jeśli chodzi o Europę, to

* Uniwersytet Warszawski.

${ }^{1}$ FAO, IFAD, UNICEF, WFP and WHO. The State of Food Security and Nutrition in the World 2020. Transforming food systems for affordable healthy diets, FAO, Rome 2020, s. XVI, http://www.fao.org/3/ca9692en/CA9692EN.pdf [dostęp: 22.02.2021].

${ }^{2}$ Ibidem, s. XVII-XIX.

${ }^{3}$ Ibidem, s. XXII. 
osiągnięto ogromny sukces w zwalczaniu głodu i niedożywienia, jednak od 2017 r. zauważa się obniżenie bezpieczeństwa żywnościowego, na co wskazuje skala niepewności żywnościowej ${ }^{4}$. Zwraca się także uwagę, że jednym z czynników zapewnienia bezpieczeństwa żywnościowego jest odpowiednie zarządzanie zasobami naturalnymi, w tym gruntami rolnymi, zwłaszcza w kontekście zmian klimatycznych ${ }^{5}$. Istotnym problemem w Europie jest degradacja gruntów rolnych, powodowana przez niewłaściwą gospodarkę rolną, co negatywnie wpływa zarówno na bezpieczeństwo żywnościowe, jak i na sam ekosystem ${ }^{6}$.

O stanie bezpieczeństwa żywnościowego w Unii Europejskiej traktuje przyjęta przez Komisję Europejską strategia „Od pola do stołu”, nastawiona na promowanie zrównoważonej gospodarki żywnościowej. Dokument ten zawiera wiele odniesień do bezpieczeństwa żywnościowego i podkreśla, że transformacja w kierunku zrównoważonych systemów żywnościowych nie obędzie się bez zmiany diety.

W Polsce odniesienie zarówno do bezpieczeństwa żywnościowego, jak i do zrównoważonego rolnictwa zawiera preambuła do ustawy o kształtowaniu ustroju rolnego ${ }^{7}$, która została dodana do ustawy w 2016 r. ustawą o wstrzymaniu sprzedaży nieruchomości Zasobu Własności Rolnej Skarbu Państwa oraz o zmianie niektórych ustaw ${ }^{8}$. W preambule wskazano, że ustawa o kształtowaniu ustroju rolnego została uchwalona m.in. w trosce o zapewnienie bezpieczeństwa żywnościowego obywateli i w celu wspierania zrównoważonego rolnictwa prowadzonego w zgodzie $\mathrm{z}$ wymogami ochrony środowiska oraz sprzyjającego rozwojowi obszarów wiejskich.

W literaturze w różnych kontekstach i ujęciach obszernie omawiana jest problematyka ograniczeń w obrocie nieruchomościami rolnymi ${ }^{9}$,

${ }^{4}$ The State of Food Security and Nutrition in Europe and Central Asia 2017, FAO, Budapest 2017, http://www.fao.org/3/I8194EN/i8194en.pdf [dostęp: 22.02.2021].

${ }^{5}$ Ibidem, s. 6.

${ }^{6}$ Ibidem, s. 37.

${ }^{7}$ Ustawa z 11 kwietnia 2003 r. o kształtowaniu ustroju rolnego (t.j. Dz. U. z 2021 r., poz. 234; dalej: u.k.u.r.).

${ }^{8}$ Ustawa z 14 kwietnia 2016 r. o wstrzymaniu sprzedaży nieruchomości Zasobu Własności Rolnej Skarbu Państwa oraz o zmianie niektórych ustaw (Dz. U. poz. 585).

9 A. Lichorowicz, Instrumenty oddziatywania na strukture gruntowa Polski w ustawie z 11 kwietnia 2003 r. o ksztaltowaniu ustroju rolnego, „Kwartalnik Prawa Prywatnego” 2004, nr 2; idem, Regulacja obrotu gruntami rolnymi wedlug ustawy z 11 kwietnia 2003 r. o ksztaltowaniu ustroju rolnego na tle ustawodawstwa agrarnego Europy Zachodniej, „Studia Iuridica Agraria” 2005, t. IV; K. Marciniuk, Prawne instrumenty ingerencji władzy publicznej w obrót nieruchomościami rolnymi jako środki kształtowania ustroju rolnego, Białystok 2019; P. Księżak, J. Mikołajczyk (red.), Nieruchomości rolne w praktyce notarialnej, Warszawa 2017; Z. Truszkiewicz, Zakres stosowania ustawy o ksztaltowaniu ustroju rolnego po nowelizacji z 2016 r., „Rejent” 2017, nr 7; 
bezpieczeństwa żywnościowego ${ }^{10}$ oraz zrównoważonych systemów żywnościowych ${ }^{11}$, ale zagadnienia te nie były dotąd analizowane łącznie. Niniejszy artykuł może więc stanowić przyczynek do dyskusji nad polskimi regulacjami prawnymi w kontekście bezpieczeństwa żywnościowego, ale postrzeganego przez pryzmat strategii „Od pola do stołu”, wyznaczającej trend zmian, jakie będą następować w Unii Europejskiej w kierunku zrównoważonych systemów żywnościowych. W artykule zarysowano relacje między ograniczeniami $\mathrm{w}$ obrocie nieruchomościami rolnymi wprowadzonymi ustawą o kształtowaniu ustroju rolnego, bezpieczeństwem żywnościowym oraz zrównoważonymi systemami żywnościowymi, a także rozważono, na ile polska regulacja obrotu nieruchomościami rolnymi może być postrzegana jako instrument zapewnienia bezpieczeństwa żywnościowego oraz czy przyjęte w niej rozwiązania prawne wpisują się w strategię „Od pola do stołu”.

\section{Strategia „Od pola do stołu”}

Komunikat pod nazwą Strategia „Od pola do stołu” na rzecz sprawiedliwego, zdrowego i przyjaznego dla środowiska systemu żywnościowego ${ }^{12}$ został przyjęty przez Komisję Europejską w maju 2020 r. Strategia ta stanowi jeden z głównych elementów Europejskiego Zielonego Ładu ${ }^{13}$, określonego we wcześniejszym komunikacie Komisji, ogłoszonym w 2019 r., a będącego nową strategią rozwoju Unii Europejskiej.

idem, Dziedziczenie i dziat spadku po nowelizacji z 2016 r. ustawy o ksztaltowaniu ustroju rolnego, „Rejent” 2018, nr 1; M. Korzycka (red.), Instytucje prawa rolnego, Warszawa 2017; J. Pisuliński, O niektórych osobliwościach obrotu nieruchomościami rolnymi, „Rejent” 2016, nr 5.

${ }^{10}$ S. Kowalczyk (red.), Bezpieczeństwo żywności w erze globalizacji, Warszawa 2009; K. Leśkiewicz, Bezpieczeństwo żywnościowe i bezpieczeństwo żywności-aspekty prawne, „Przegląd Prawa Rolnego" 2012, nr 1, s. 179-197; M. Korzycka, P. Wojciechowski, System prawa żywnościowego, Warszawa 2017; Leśkiewicz, Prawo żywnościowe, Warszawa 2020.

${ }^{11}$ K. Leśkiewicz, Zrównoważone systemy żywnościowe w kontekście reformy Wspólnej Polityki Rolnej - aspekty prawne, „Przegląd Prawa Rolnego” 2020, nr 2, s. 75-85; T. Srogosz, Systemy żywnościowe w kontekście Zrównoważonych Celów Rozwoju - kilka uwag w czasie pandemii, „Przegląd Prawa Publicznego” 2020, nr 6, s. 24-37; M. Żuchowska-Grzywacz, Zrównoważony produkt żywnościowy w systemie prawa - fakt czy życzenie?, „Problemy Jakości” 2018, nr 12, s. 7-12.

${ }^{12}$ Komunikat Komisji do Parlamentu Europejskiego, Rady, Europejskiego Komitetu Ekonomiczno-Społecznego i Komitetu Regionów, Strategia „Od pola do stołu” na rzecz sprawiedliwego, zdrowego i przyjaznego dla środowiska systemu żywnościowego, $\operatorname{COM(2020)} 381$ final.

${ }^{13}$ Komunikat Komisji do Parlamentu Europejskiego, Rady Europejskiej, Rady, Komitetu Ekonomiczno-Społecznego I Komitetu Regionów, Europejski Zielony Ład, COM(2019) 640 final. 
Zarówno Europejski Zielony Ład, jak i strategia „Od pola do stołu” są dokumentami o charakterze strategicznym, które wyznaczają kierunki zakładanych zmian, ale to dopiero regulacje prawne będą wprowadzały prawnie wiążące rozwiązania. Znaczenie tych dokumentów jest jednak o tyle istotne, że definiują one konkretne cele i założenia oraz wyznaczają kierunki, w jakich podążać będzie unijny legislator.

Zgodnie z założeniem Komisji Europejski Zielony Ład to strategia na rzecz wzrostu, której celem jest przekształcenie UE w sprawiedliwe i prosperujące społeczeństwo żyjące w nowoczesnej, zasobooszczędnej i konkurencyjnej gospodarce, która w 2050 r. osiągnie zerowy poziom emisji gazów cieplarnianych netto i w ramach której wzrost gospodarczy będzie niezależny od wykorzystania zasobów naturalnych ${ }^{14}$. W dokumencie tym przedstawiono wstępny plan działania obejmujący główne polityki i środki niezbędne do osiągnięcia Europejskiego Zielonego Ładu. Dokument ten dotyczy wielu aspektów unijnej gospodarki. Europejski Zielony Ład stanowi integralną część opracowanej przez obecną Komisję strategii mającej na celu wdrożenie Agendy ONZ na rzecz zrównoważonego rozwoju 2030 i celów zrównoważonego rozwoju ${ }^{15}$.

Jak podkreślono w tym dokumencie, europejska żywność słynie z bezpieczeństwa, bogactwa w wartości odżywcze i wysokiej jakości, ale powinna również stać się światowym standardem zrównoważoności ${ }^{16}$. Oceniono bowiem, że produkcja żywności wciąż powoduje zanieczyszczenie powietrza, wody i gleby, przyczynia się do utraty różnorodności biologicznej i zmiany klimatu oraz pochłania ogromne ilości zasobów naturalnych, a jednocześnie marnuje się dużą część wyprodukowanej żywności ${ }^{17}$.

W dokumencie tym zauważono też, że europejska żywność jest już światowym standardem żywności, która jest bezpieczna, pełnowartościowa, wysokiej jakości i dostępna w wystarczającej ilości, natomiast strategia „Od pola do stołu" ma na celu nagrodzenie tych rolników, rybaków i innych podmiotów w łańcuchu żywnościowym, którzy przeszli już transformację w kierunku zrównoważonych praktyk, oraz umożliwienie takiej transformacji innym i stworzenie dla nich dodatkowych możliwości biznesowych ${ }^{18}$.

Podkreślono jednak, że globalne wyzwania związane z klimatem i ochroną środowiska stanowią czynnik zwielokrotniający zagrożenia i są źródłem niestabilności, zaś transformacja ekologiczna będzie dużym wy-

\footnotetext{
14 Ibidem, s. 2.

${ }^{15}$ Ibidem, s. 3.

${ }^{16}$ Ibidem, s. 13.

17 Ibidem, s. 14.

${ }^{18}$ Strategia „Od pola do stołu”, s. 3.
} 
zwaniem dla wielu państw i społeczeństw. Istotne jest zatem takie wprowadzanie zmian, aby skutki polityki klimatycznej nie stały się źródłem konfliktów, braku bezpieczeństwa żywnościowego, przesiedlania ludności i przymusowej migracji ${ }^{19}$.

Częścią Europejskiego Zielonego Ładu jest strategia „Od pola do stołu”. Uwzględnia ona wszelkie wyzwania związane ze zrównoważonymi systemami żywnościowymi i uznaje za nierozerwalny związek między zdrowymi ludźmi, zdrowymi społeczeństwami i zdrową planetą ${ }^{20}$. Samo pojęcie zrównoważonych systemów żywnościowych nie zostało w tym dokumencie zdefiniowane, jednak - jak słusznie wskazuje się w literaturze - zrównoważone systemy żywnościowe mogą oznaczać układ lub układy logicznie powiązanych elementów w sferze wytwarzania, przetwarzania produktów rolnych lub żywności, o opanowanym (zrównoważonym) charakterze ${ }^{21}$.

Pojęcie zrównoważonych systemów żywnościowych jest niejako wpisane w problematykę zrównoważonego rozwoju szeroko omawianego w literaturze i prezentowanego w wielu ujęciach: prawnym, ekonomicznym i społecznym ${ }^{22}$. Mimo wieloletniej dyskusji samo pojęcie zrównoważonego rozwoju (sustainable development) nie zostało dotąd precyzyjnie zdefiniowane ${ }^{23}$. Najogólniej można stwierdzić, że zrównoważony rozwój oznacza rozwój społeczno-gospodarczy uwzględniający wymogi środowiskowe oraz wymogi sprawiedliwości międzypokoleniowej. Zrównoważony rozwój jest strategią, której głównym celem jest osiągnięcie globalnej sprawiedliwości w sposobie życia oraz dostępie do zasobów ${ }^{24}$.

19 Europejski Zielony Ład, s. 25.

${ }^{20}$ Strategia „Od pola do stołu”, s. 2.

${ }^{21}$ K. Leśkiewicz, Zrównoważone systemy żywnościowe..., s. 80.

22 Z. Bukowski, Zrównoważony rozwój w systemie prawa, Torun 2012, s. 26; E. Olejarczyk, Zasada zrównoważonego rozwoju w systemie prawa polskiego - wybrane zagadnienia, „Przegląd Prawa Ochrony Środowiska” 2016, nr 2, s. 121.

${ }^{23}$ Warto przypomnieć, że pod koniec lat 90. miała miejsce polemika dotycząca adekwatnego przekładu terminu sustainable development na język polski. M. Kenig-Witkowska wskazała, że w języku polskim odpowiednikiem pojęcia sustainable development jest „ciągły rozwój”. Takie terminy, jak rozwój ekologiczny, rozwój zrównoważony, ekorozwój, wydają się znacznie mniej fortunne, a nawet źle oddające istotę samego problemu. Zob. M. Kenig-Witkowska, Koncepcja sustainable development w prawie międzynarodowym, „Państwo i Prawo” 1998, nr 8, s. 45 i n. Z kolei w dyskusji tej M. Sitek wskazała, że koncepcja sustainable development powinna zmierzać nie tylko do zagwarantowania ciągłego rozwoju poszczególnych kategorii polityk (ekonomicznej, ochrony środowiska, społecznej itp.), ale także do ich zharmonizowania lub, inaczej mówiąc, zrównoważenia. Zob. M Sitek, Sustainable development - ciagły czy zrównoważony rozwój?, „Państwo i Prawo” 1999, nr 2.

${ }^{24}$ Z. Bukowski, Zrównoważony rozwój..., s. 26. 
Pojęcie zrównoważonych systemów żywnościowych odnosi się do wielu sfer funkcjonowania sektora żywnościowego. W zależności od kontekstu może dotyczyć całego łańcucha żywnościowego (i to na szczeblu globalnym, unijnym lub krajowym), poszczególnych jego etapów (od produkcji pierwotnej, przez przetwarzanie żywności, po jej dystrybucję), a nawet - już poza tradycyjnie rozumianym łańcuchem żywnościowym - sfery konsumpcji żywności oraz gospodarki odpadami żywnościowymi. Wszystkie te elementy oddziałują bowiem na środowisko oraz mają znaczenie gospodarcze i społeczne, a zatem do osiągnięcia stanu zrównoważenia systemów żywnościowych konieczne jest podjęcie różnych działań zarówno przez Unię Europejską, jak i poszczególne państwa na etapie tworzenia warunków do produkcji żywności, w tym regulacji dostępu do gruntów rolnych, a także na etapach wytwarzania, przetwarzania, dystrybucji żywności, jej konsumpcji oraz postępowania z odpadami żywnościowymi.

W strategii „Od pola do stołu” zwrócono uwagę, że transformacja UE w kierunku zrównoważonych systemów żywnościowych rozpoczęła się w wielu obszarach, jednak systemy żywnościowe nadal w dużej mierze przyczyniają się do zmiany klimatu i degradacji środowiska, w związku z czym należy pilnie zmniejszyć ich zależność od pestycydów i środków przeciwdrobnoustrojowych, ograniczyć nadmierne nawożenie, wzmocnić rolnictwo ekologiczne, poprawić dobrostan zwierząt oraz odwrócić proces utraty różnorodności biologicznej ${ }^{25}$.

Zaznacza się też, że zrównoważony system żywnościowy będzie miał zasadnicze znaczenie dla osiągnięcia celów klimatycznych i środowiskowych Zielonego Ładu, przy jednoczesnym zwiększeniu dochodów producentów surowców i wzmocnieniu konkurencyjności UE, a w ramach tej strategii wspiera się transformację, kładąc nacisk na nowe możliwości zarówno dla obywateli, jak i podmiotów prowadzących przedsiębiorstwa spożywcze ${ }^{26}$.

W strategii „Od pola do stołu” za cel UE uznano zmniejszenie śladu środowiskowego i klimatycznego unijnego systemu żywnościowego, a jednocześnie zapewnienie bezpieczeństwa żywnościowego w obliczu zmiany klimatu i utraty różnorodności biologicznej oraz doprowadzenie do tego, aby UE była liderem globalnej transformacji w kierunku konkurencyjnej zrównoważoności od pola do stołu ${ }^{27}$. Zwrócono przy tym uwagę, że coraz częstsze występowanie suszy, powodzi, pożarów lasów i nowych agrofagów

\footnotetext{
${ }^{25}$ Strategia „Od pola do stołu”, s. 3.

${ }^{26}$ Ibidem, s. 4.

${ }^{27}$ Ibidem, s. 5.
} 
nieustannie przypomina o tym, że nasz system żywnościowy jest zagrożony i musi stać się bardziej zrównoważony i odporny ${ }^{28}$.

Jak podkreślono w strategii, konieczne jest zapewnienie bezpieczeństwa żywnościowego, żywienia i zdrowia publicznego, a więc powszechnego dostępu do wystarczającej ilości pełnowartościowej i zrównoważonej żywności, spełniającej wysokie standardy bezpieczeństwa i jakości, zdrowia roślin oraz zdrowia i dobrostanu zwierząt, przy jednoczesnym zaspokajaniu potrzeb i preferencji żywieniowych. Za ważne uznano zapewnienie przystępności cenowej żywności przy bardziej sprawiedliwym podziale zysków ekonomicznych w łańcuchu dostaw, aby najbardziej zrównoważona żywność stała się także najbardziej przystępna cenowo ${ }^{29}$.

W świetle założeń strategii „Od pola do stołu” nie budzi zatem wątpliwości, że uczynienie systemów żywnościowych bardziej zrównoważonymi oznacza z jednej strony konieczność dostosowania ich do wymagań związanych z realizacją celu w postaci osiągnięcia neutralności klimatycznej-wytwarzanie żywności powinno bowiem wspierać przeciwdziałanie zmianom klimatycznym, sprzyjać ochronie środowiska i zachowaniu bioróżnorodności, z drugiej strony żywność musi pozostać bezpieczna i bogata w wartości odżywcze oraz zachować wysoką jakość, a przede wszystkim być przystępna cenowo. Kwestia bezpieczeństwa żywnościowego jest ujmowana w strategii jako warunek konieczny i podstawowy przy wprowadzaniu wszelkich zmian w systemach żywnościowych. Na ścisły związek między zrównoważonymi systemami żywnościowymi a bezpieczeństwem żywnościowym zwraca się też uwagę w literaturze ${ }^{30}$.

W strategii „Od pola do stołu” uwzględniono również doświadczenia związane z pandemią COVID-19, która uwydatniła znaczenie systemu żywnościowego, w tym zapewnienia obywatelom, niezależnie od okoliczności, dostępu do wystarczającej ilości żywności w przystępnej cenie ${ }^{31}$. System zrównoważonej żywności powinien bowiem zapewniać ludziom wystarczającą i zróżnicowaną ofertę bezpiecznej, pełnowartościowej i przystępnej cenowo zrównoważonej żywności przez cały czas, także w okresach kryzysów. Kryzysy, zależnie od ich charakteru (polityczne, gospodarcze, środowiskowe, zdrowotne), skali (lokalne, regionalne, globalne) i okresu trwania, na różne sposoby wpływają na bezpieczeństwo żywnościowe. Mimo że w Unii Europejskiej zaopatrzenie w żywność jest wystarczające, pande-

28 Ibidem, s. 2.

29 Ibidem, s. 5.

${ }^{30}$ K. Leśkiewicz, Zrównoważone systemy żywnościowe..., s. 76; T. Srogosz, Systemy żywnościowe..., s. 24-37.

31 Strategia „Od pola do stołu”, s. 2. 
mia COVID-19 ujawniła wiele zagrożeń, takich jak logistyczne zakłócenia łańcuchów dostaw, niedobory siły roboczej, utrata niektórych rynków oraz zmiana wzorców konsumpcji, które mają wpływ na funkcjonowanie systemów żywnościowych ${ }^{32}$. Obecna sytuacja jest zatem bezprecedensowa, a niezależnie od kryzysu wywołanego pandemią łańcuch żywnościowy staje przed coraz większymi wyzwaniami w związku z nawracającymi suszami, powodziami, pożarami lasów, utratą różnorodności biologicznej i nowymi agrofagami. Komisja Europejska zobowiązała się do wypracowania wspólnej europejskiej reakcji na sytuacje kryzysowe mające wpływ na systemy żywnościowe, aby zapewnić bezpieczeństwo żywnościowe i dostęp do żywności, wzmocnić zdrowie publiczne i złagodzić skutki społeczno-gospodarcze tych sytuacji kryzysowych w $\mathrm{UE}^{33}$.

W strategii „Od pola do stołu” zauważono, że konsumenci zwracają coraz większą uwagę na kwestie środowiskowe, zdrowotne, społeczne i etyczne i bardziej niż kiedykolwiek oczekują, że żywność będzie świeża, mniej przetworzona i pozyskiwana w zrównoważony sposób ${ }^{34}$.

Można na tej podstawie stwierdzić, że instytucje unijne dostrzegają konieczność zmian w procesach wytwarzania, przetwarzania i dystrybucji żywności, które doprowadzą do zdecydowanego ograniczenia negatywnego wpływu całego łańcucha żywnościowego na środowisko i klimat, przy jednoczesnym zapewnieniu dostępu do odpowiedniej żywności.

\section{Pojęcie bezpieczeństwa żywnościowego}

Pojęcie „bezpieczeństwo żywnościowe” (food security) jest szeroko wykorzystywane w publikacjach naukowych i różnego rodzaju dokumentach o charakterze międzynarodowym, a także w prawie. Koncepcja bezpieczeństwa żywnościowego została ukształtowana podczas pierwszej Światowej Konferencji Żywnościowej, która odbyła się w Rzymie w 1974 r. pod auspicjami Organizacji ds. Wyżywienia i Rolnictwa (Food and Agriculture Organization, FAO) ${ }^{35}$. Pojęcie to używane jest w różnych kontekstach i przypisywane jest mu różne znaczenie ${ }^{36}$, jednak najczęściej przywoływana

32 Ibidem, s. 13.

33 Ibidem.

34 Ibidem, s. 3.

35 T. Rodríguez-Cachón, Commission I, National report Spain, European Congress of Agricultural Law, 18-21 September 2019 Poznań (Poland), s. 5.

36 Już w latach 80. można było odnaleźć ponad 200 propozycji definicji bezpieczeństwa żywnościowego. Zob. S. Maxwell, M. Smith, Household food security; a conceptual review, w: S. Maxwell, T.R. Frankenberger (red.), Household Food Security: Concepts, Indicators, Mea- 
i powszechnie akceptowana jest definicja, która została zatwierdzona na Światowym Szczycie Żywnościowym w 1996 r. Zgodnie z nią „,bezpieczeństwo żywnościowe istnieje, gdy wszyscy ludzie przez cały czas mają fizyczny i ekonomiczny dostęp do wystarczającej, bezpiecznej i pożywnej żywności, aby zaspokoić swoje potrzeby dietetyczne i preferencje żywieniowe dla aktywnego i zdrowego życia"37. Można przy tym mówić o czterech filarach bezpieczeństwa żywnościowego: istnienie żywności, jej dostępność, stabilność dostaw oraz odpowiedniość żywności. W kontekście sytuacji w Unii Europejskiej także wymiar żywieniowy (tj. odpowiedniość żywności do potrzeb żywieniowych) jest integralną częścią koncepcji bezpieczeństwa żywnościowego ${ }^{38}$. Można zatem stwierdzić, że bezpieczeństwo żywnościowe oznacza ogół warunków jakie muszą być spełnione dla zapewnienia wystarczającej ilości żywności (tj. dostępności i stabilności dostaw żywności odpowiedniej do aktywnego i zdrowego życia) niezbędnej do wyżywienia ludności świata, a w węższym ujęciu - określonego regionu czy państwa ${ }^{39}$. Zważywszy na ogromne zróżnicowanie sytuacji ekonomicznej i gospodarczej, bezpieczeństwo żywnościowe na świecie może być osiągnięte jedynie w oparciu o etykę solidarności ${ }^{40}$.

Wobec stwierdzeń zawartych w strategii „Od pola do stołu” należy uznać, że w Unii Europejskiej o bezpieczeństwie żywnościowym może być mowa dopiero wtedy, gdy konsumenci będą mieli dostęp do żywności przetworzonej i pozyskiwanej w zrównoważony sposób.

Bezpieczeństwo żywnościowe jest też brane pod uwagę w kontekście celów zrównoważonego rozwoju ustalonych w Agendzie na rzecz zrówno-

surements: A Technical Review, New York - Rome 1993, za: Commodity Policy and Projections Service Commodities and Trade Division, FAO, Rome 2003, pkt 2.2, http://www.fao.org/3/y4671e/ y4671e06.htm\#bm06 [dostęp: 24.02.2021].

37 World Food Summit Plan of Action, World Food Summit, Rome, 13-17 November 1996, http://www.fao.org/3/w3613e/w3613e00.htm [dostęp 24.02.2021]. Taka sama definicja została zawarta w deklaracji Światowego Szczytu Bezpieczeństwa Żywnościowego z 2009 r. Draft Declaration of the World Summit on Food Security, Rome, 16-18 November 2009, http://www.fao. org/fileadmin/templates/wsfs/Summit/Docs/Declaration/WSFS09_Draft_Declaration.pdf [dostęp: 24.02.2021].

${ }^{38}$ Draft Declaration..., s. 1.

${ }^{39}$ K. Mechlem, Food Security and the Right to Food in the Discourse of the United Nation, „European Law Journal” 2004, nr 10(5); K. Leśkiewicz, Bezpieczeństwo żywnościowe i bezpieczeństwo żywności - aspekty prawne, „Przegląd Prawa Rolnego” 2012, nr 1, s. 179; M. Korzycka, Prawa człowieka w prawie żywnościowym, w: M. Korzycka, P. Wojciechowski, System prawa żywnościowego, Warszawa 2017, s. 497.

${ }^{40}$ Przemówienie papieża Jana Pawła II z 13.11.1996 r. podczas World Food Summit, Food and Agriculture Organization of the United Nations, http://www.fao.org/3/w3548e/w3548e00. htm [dostęp: 24.02.2021]. 
ważonego rozwoju $2030^{41}$. Jak wskazuje się w tym dokumencie, prezentowane $\mathrm{w}$ nim cele i zadania opierają się na niezwykle ambitnej wizji zmiany świata, w którym wszyscy ludzie mają dostęp do wystarczającej ilości bezpiecznej, pożywnej i przystępnej cenowo żywności ${ }^{42}$. W dokumencie tym przyjęto 17 celów, a drugi z nich brzmi następująco: „Wyeliminować głód, osiągnąć bezpieczeństwo żywnościowe i lepsze odżywianie oraz promować zrównoważone rolnictwo"43. W ramach tego celu przewiduje się do $2030 \mathrm{r}$. podwoić wydajność rolnictwa i dochody drobnych producentów żywności, w szczególności kobiet, rdzennej ludności, rodzinnych gospodarstw rolnych, pasterzy i rybaków, m.in. poprzez bezpieczny i równy dostęp do ziemi oraz innych zasobów i czynników produkcji, dostęp do wiedzy, usług finansowych i rynków oraz możliwości zwiększenia wartości dodanej i zatrudnienia poza sektorem rolniczym ${ }^{44}$.

W dokumencie tym zwrócono też uwagę na ważną rolę Komitetu ds. Światowego Bezpieczeństwa Żywnościowego (Committee on World Food Security, CWFS ${ }^{45}$. W jednym z przygotowanych przez ten Komitet opracowań wśród różnych zaleceń kierowanych do państw wskazano, że państwa powinny podjąć środki zapobiegające niepożądanemu wpływowi na społeczności lokalne, ludność miejscową i wrażliwe grupy, który może wynikać m.in. ze spekulacji gruntów, koncentracji gruntów i nadużywania zwyczajowych form własności, a także to, że państwa powinny ustanowić przepisy i systemy regulacyjne zapewniające transparentność rynku nieruchomości rolnych oraz ułatwiające udział w tym rynku osób biednych i najsłabszych, jak również to, że powinny promować odpowiedzialne inwestycje w grunty, które wspierają wzrost społeczny i gospodarczy oraz

${ }^{41}$ Rezolucja Zgromadzenia Ogólnego A/RES/70/1: Agenda na rzecz zrównoważonego rozwoju 2030, przyjęta przez Zgromadzenie Ogólne ONZ 25 września 2015 r., http://unic.un.org.pl/ files/164/Agenda\%202030_pl_2016_ostateczna.pdf [dostęp: 24.02.2021].

42 Ibidem, s. 7.

43 Ibidem, s. 16.

${ }^{44}$ Ibidem, s. 17.

${ }^{45}$ Ibidem, s. 8. Komitet Światowego Bezpieczeństwa Żywnościowego (CFS) jest najważniejszą międzynarodową i międzyrządową platformą dla wszystkich zainteresowanych stron, służącą współpracy w celu zapewnienia bezpieczeństwa żywnościowego. Komitet składa sprawozdanie Zgromadzeniu Ogólnemu ONZ za pośrednictwem Rady Ekonomiczno-Społecznej i konferencji FAO. CFS opracowuje i zatwierdza zalecenia polityczne i wytyczne dotyczące szerokiego zakresu zagadnień bezpieczeństwa żywności i żywienia. Są one opracowywane na podstawie raportów naukowych i opartych na dowodach opracowanych przez panel ekspertów wysokiego szczebla ds. bezpieczeństwa żywności i żywienia (HLPE) lub poprzez prace wspierane technicznie przez Organizację ds. Żywności i Rolnictwa (FAO), Międzynarodowy Fundusz Rozwoju Rolnictwa (IFAD), Światowy Program Żywnościowy (WFP) i przedstawicieli Grupy Doradczej CFS. Zob. http://www.fao.org/cfs/en/ [dostęp: 24.02.2021]. 
zrównoważony rozwój społeczny, koncentrując się na drobnych gospodarstwach $^{46}$. Ponadto wskazano, że grunty rolne mają kluczowe znaczenie dla osiągania celów w zakresie praw człowieka, bezpieczeństwa żywnościowego, eliminacji ubóstwa, zapewnienia stabilnych środków utrzymania, stabilności społecznej, bezpieczeństwa mieszkaniowego, rozwoju obszarów wiejskich oraz rozwoju społeczno-gospodarczego ${ }^{47}$. W dokumentach przygotowywanych przez CWFS twierdzi się, że nabywanie dużych powierzchni nieruchomości rolnych wiąże się z obniżeniem stanu bezpieczeństwa żywnościowego ${ }^{48}$, a także wskazuje się, że państwa powinny nadać priorytet inwestycjom $w$ sektorze małych gospodarstw $i$ alternatywnym, proekologicznym systemom produkcji żywności, co z jednej strony jest korzystne społecznie, a $z$ drugiej - zrównoważone środowiskowo ${ }^{49}$. Również w innych dokumentach łączy się bezpieczeństwo żywnościowe $\mathrm{z}$ dostępem do gruntów rolnych ${ }^{50}$.

Coraz częściej zwraca się też uwagę, że zachodzące zmiany klimatyczne mają wpływ na bezpieczeństwo żywnościowe ${ }^{51}$. Stopniowe zmiany średnich temperatur i opadów deszczu decydują o przydatności gruntów pod różne rodzaje upraw i pastwisk, co może skutkować np. pogorszeniem, a nawet zmniejszeniem areału gruntów ornych ze względu na wynikający z nich wzrost jałowości gruntów, zubożenie wód gruntowych i wzrost poziomu morza $^{52} . \mathrm{Z}$ drugiej strony, aby ograniczyć negatywny wpływ na środowisko produkcji rolnej, zachęca się do podejmowania produkcji mniej ekstensywnej, opartej na metodach ekologicznych, która jest jednak znacznie mniej wydajna, co oznacza, że z tego samego areału uzyskuje się mniejsze plony ${ }^{53}$.

${ }^{46}$ Voluntary Guidelines on the responsible governance of tenure of land, fisheries and forests in the context of national food security, FAO, Rome 2012, s. 18-20, http://www.fao.org/3/i2801e/ i2801e.pdf [dostęp: 24.02.2021].

47 Ibidem, s. 6.

${ }^{48}$ Land tenure and international investments in agriculture. A report by the High Level Panel of Experts on Food Security and Nutrition of the Committee on World Food Security, HLPE, Rome 2011, s. 34, http://www.fao.org/3/a-mb766e.pdf [dostęp: 24.02.2021].

${ }^{49}$ Ibidem, s. 43.

${ }^{50}$ Voluntary Guidelines to support the progressive realization of the right to adequate food in the context of national food security, FAO, Rome 2005, s. 16-17, http://www.fao.org/3/y7937e/ y7937e00.pdf [dostęp: 24.02.2021].

${ }_{51}$ B.M. Campbell i in., Reducing risks to food security from climate change, „Global Food Security" 2016, t. 11, https://www.sciencedirect.com/science/article/pii/S2211912415300262 [dostęp: 24.02.2021]; Climate change and food security: a framework document, FAO, Rome 2008, http:// www.fao.org/forestry/15538-079b31d45081 fe9c3dbc6ff34de4807e4.pdf [dostęp: 24.02.2021].

${ }_{52}$ Climate change and food security..., s. 12.

${ }^{53}$ HLPE Report on Agroecological and other innovative approaches for sustainable agriculture and food systems that enhance food security and nutrition. Extract from the Report: 
W dłuższej perspektywie oba te czynniki wpływają na zwiększenie znaczenia gruntów rolnych i pośrednio na bezpieczeństwo żywnościowe państw unijnych. W dokumentach unijnych można zresztą znaleźć odniesienie do bezpieczeństwa żywnościowego w kontekście kwestii obrotu nieruchomościami rolnymi. W rezolucji Parlamentu Europejskiego w sprawie aktualnego stanu koncentracji gruntów rolnych w $\mathrm{UE}^{54}$ zwrócono uwagę na to, że wysokiej jakości grunty rolne mają decydujące znaczenie m.in. dla bezpieczeństwa żywnościowego oraz że ze względu na zapotrzebowanie na żywność i pasze, paliwa niekopalne i odnawialne surowce dla przemysłu paliwowego, chemicznego i tekstylnego oraz dla biogospodarki ich wartość stale rośnie, a wraz z tym wzrastają ceny ziemi ${ }^{55}$. Ponadto Parlament Europejski zaznaczył, że około $20 \%$ europejskich użytków rolnych już zostało dotknięte skutkami zmiany klimatu, erozji gleby pod wpływem wody i wiatru oraz nieprofesjonalnego gospodarowania, a w wyniku globalnego ocieplenia niektóre regiony UE, szczególnie w południowej Europie, są narażone na susze i inne ekstremalne zjawiska pogodowe, co spowoduje pogorszenie jakości gleby i ograniczy dostępność gruntów wysokiej jakości i gruntów nadających się do użytkowania w rolnictwie ${ }^{56}$. Zwrócił też uwagę, że czynnikiem pozytywnie wpływającym m.in. na bezpieczeństwo żywnościowe jest struktura agrarna oparta na małych i średnich gospodarstwach, rozproszonej własności lub właściwie uregulowanej dzierżawie i dostępie do wspólnych gruntów, gdyż takie rozwiązania są wyrazem odpowiedzialnego traktowania ziemi i zrównoważonej gospodarki gruntami, a ponadto sprzyjają utożsamianiu się i poczuciu przynależności ${ }^{57}$. Parlament w swojej rezolucji wyraził potrzebę przyznania gruntom rolnym szczególnej ochrony w celu umożliwienia państwom członkowskim - w koordynacji z władzami lokalnymi i organizacjami rolników - regulowania sprzedaży, użytkowania i dzierżawienia gruntów rolnych właśnie w celu zapewnienia bezpieczeństwa żywnościowego ${ }^{58}$.

Podobnie Komisja Europejska w komunikacie wyjaśniającym w sprawie nabywania gruntów rolnych zauważa m.in., że grunty rolne mają kluczowe

Summary and Recommendations (19 June 2019), http://www.fao.org/fileadmin/user_upload/ hlpe/hlpe_documents/HLPE_S_and_R/HLPE_2019_Agroecological-and-Other-Innovative-Approaches_S-R_EN.pdf [dostęp: 24.02.2021].

${ }^{54}$ Rezolucja Parlamentu Europejskiego z 27.04.2017 r. w sprawie aktualnego stanu koncentracji gruntów rolnych w UE: jak ułatwić rolnikom dostęp do gruntów? (2016/2141(INI)) (Dz. Urz. UE C 298 z 2018 r., s. 112), pkt T.

55 Ibidem, pkt U.

${ }^{56}$ Ibidem, pkt S.

${ }^{57}$ Ibidem, pkt V.

58 Ibidem, pkt 37. 
znaczenie dla bezpieczeństwa żywnościowego, zwłaszcza że są zasobem ograniczonym, a na niemal połowie terytorium UE są narażone na presję związaną z wykorzystaniem pozarolniczym ${ }^{59}$. Co więcej, według Komisji nawet same obawy związane z bezpieczeństwem żywnościowym oraz programy dotyczące biopaliw i biogazu przyczyniły się do zwiększenia zainteresowania inwestorów nieruchomościami rolnymi ${ }^{60}$. Nie ma więc wątpliwości, że istnieje ścisły związek między bezpieczeństwem żywnościowym a regulacjami dotyczącymi obrotu nieruchomościami rolnymi.

Działania podejmowane przez poszczególne państwa w celu zapewnienia bezpieczeństwa żywnościowego zależą od sytuacji gospodarczej, geograficznej i społecznej i mogą polegać m.in. na wspieraniu drobnych rolników w osiąganiu zwiększania plonów, ułatwianiu dostępu do kredytów dla najbiedniejszych czy przeprowadzaniu reform rolnych służących zmniejszeniu nierówności w dostępie do gruntów rolnych ${ }^{61}$. Dostęp do gruntów jest bowiem warunkiem zapewnienia bezpieczeństwa żywnościowego i korzystania $\mathrm{z}$ prawa do odpowiedniej żywności ${ }^{62}$. Przyjmowane przez dane państwo rozwiązania powinny być jednak adekwatne do stanu bezpieczeństwa żywnościowego i nie mogą zanadto ingerować w prawa człowieka, chociażby w prawo własności.

Regulacja przyczyniająca się do rolniczego wykorzystywania gruntów rolnych stanowi przy tym warunek wstępny zapewnienia bezpieczeństwa żywnościowego. Z kolei cele stawiane w strategii „Od pola do stołu” wskazują na potrzebę wprowadzenia regulacji prawnych, które będą przyczyniać się do takiego sposobu rolniczego wykorzystania nieruchomości rolnych, który będzie prowadził do wytwarzania żywności w sposób zrównoważony.

Zasadne jest więc sprawdzenie, czy obowiązująca w Polsce regulacja ograniczająca obrót nieruchomościami może mieć pozytywny wpływ na zapewnienie bezpieczeństwa żywnościowego i czy może stanowić instrument realizacji strategii „Od pola do stołu”.

${ }^{59}$ Komunikat wyjaśniający Komisji w sprawie nabywania gruntów rolnych i prawa Unii Europejskiej (Dz. Urz. UE C 350 z 2017 r., s. 5), s. 6; opinia Europejskiego Komitetu Ekonomiczno-Społecznego w sprawie: „Masowy wykup gruntów rolnych - dzwonek alarmowy dla Europy i zagrożenie dla rolnictwa rodzinnego" (opinia z inicjatywy własnej) (Dz. Urz. UE C 242 z 2015 r., s. 15), s. 5.

${ }^{60}$ Ibidem, s. 7.

${ }^{61} \mathrm{Ch}$. Golay, M. Özden, The right to food. A fundamental human right affirmed by the United Nations and recognized in regional treaties and numerous national constitutions. Part of a series of the Human Rights Programme of the Europe-Third World Centre, Geneva 2005, s. 16.

${ }^{62}$ R. Pastuszko, Dostęp do zasobu gruntów rolnych w procesach globalizacji. Zagadnienia prawne, Lublin 2019, s. 143. 


\section{Zakres wprowadzonych ograniczeń w obrocie nieruchomościami rolnymi w kontekście bezpieczeństwa żywnościowego}

Przewidziane w ustawie o kształtowaniu ustroju rolnego ograniczenia w obrocie nieruchomościami rolnymi można zaliczyć do środków służących zapewnieniu bezpieczeństwa żywnościowego i realizacji prawa do odpowiedniej żywności. Po pierwsze, wprowadzenie w art. 2 a ust. 1 u.k.u.r. jako zasady nabywania nieruchomości przez rolników indywidualnych, z jednoczesnym wprowadzeniem szeregu wyjątków, służy ograniczeniu niekontrolowanego wykupu gruntów rolnych w Polsce przez osoby niezainteresowane prowadzeniem działalności rolniczej, często w celu lokaty kapitału ${ }^{63}$. Po drugie, wprowadzenie ograniczenia co do powierzchni gospodarstwa rolnego, na powiększenie którego można nabyć nieruchomości rolne (art. 2a ust. 2), ogranicza możliwość nabywania tych nieruchomości przez podmioty prowadzące największe gospodarstwa rolne. Zarówno możliwość nabywania nieruchomości, także w celach inwestycyjnych, jak i możliwość nieograniczonego nabywania nieruchomości rolnych przez największych rolników w przeszłości przyczyniały się do wzrostu cen nieruchomości rolnych, gdyż popyt na nieruchomości rolne zdecydowanie przewyższał podaż ${ }^{64}$. Warto zaznaczyć, że według badań Polacy traktują nieruchomości rolne jako korzystną i nieopodatkowaną lokatę kapitału, poza tym dla rolników są to aktywa mogące przynosić stały dochód (np. czynsz z dzierżawy, środki z funduszy unijnych), co zniechęca do ich zbycia właścicieli i winduje cenę ${ }^{65}$. Poprzez ograniczenie kręgu osób uprawnionych do nabycia nieruchomości rolnych ustawodawca dąży do zmniejszenia presji cenowej i ułatwienia dostępu do nieruchomości rolnych rolnikom indywidualnym, prowadzącym gospodarstwa rodzinne, stanowiące podstawę ustroju rolnego w Polsce. Należy przy tym podkreślić, że rolnicy indywidualni, jako osoby posiadające odpowiednie

${ }^{63} \mathrm{~W}$ połowie pierwszej dekady XXI w. nieruchomości rolne przestały być traktowane jako środek produkcji przeznaczony wyłącznie dla osób związanych z rolnictwem, a zaczęły być przedmiotem zainteresowania inwestorów, zarówno indywidualnych, jak i instytucjonalnych, jako lokata kapitału, co spowodowało wzrost popytu na ziemię rolną i związany z tym wzrost cen. W latach 2004-2014 lokata kapitału w grunty rolne należała do najbardziej dochodowych, co było szczególnie widoczne w państwach, które przystąpiły do UE w 2004 i 2007 r. Zob. S. Prokurat, Ekonomiczne i prawne aspekty obrotu ziemia w Polsce na tle rynku europejskiego, ,Acta Universitatis Wratislaviensis. Ekonomia - Wroclaw Economic Review” 2017, nr 23(3), s. 139.

${ }^{64} \mathrm{Na}$ temat zjawisk ekonomicznych na rynku nieruchomości rolnych: P. Wojciechowski, Wybrane aspekty ograniczenia obrotu nieruchomościami rolnymi w prawie polskim $w$ kontekście unijnej zasady swobody przepływu kapitału, „Przegląd Prawa Rolnego” 2020, nr 2, s. 27-28.

${ }^{65}$ S. Prokurat, Ekonomiczne i prawne aspekty..., s. 143. 
kwalifikacje rolnicze i doświadczenie w prowadzeniu gospodarstwa rolnego, są grupą społeczną, dla której dostęp do gruntów rolnych jest kluczowy w kontekście bezpieczeństwa żywnościowego. To właśnie oni dają gwarancję prowadzenia działalności rolniczej na gruntach rolnych.

Istotnym dla bezpieczeństwa żywnościowego rozwiązaniem jest także ujęcie $w$ art. $2 b$ u.k.u.r. wymogu prowadzenia gospodarstwa rolnego na nabytym gruncie przez ustalony w ustawie 5-letni okres (przed nowelizacją z 2019 r. był to 10-letni okres) i związanego z tym wymogiem ograniczenia w obrocie nieruchomościami rolnymi (brak możliwości zbycia lub oddania w posiadanie nabytej nieruchomości przez okres 5 lat). Głównym skutkiem wprowadzenia zasady, że nabywca nieruchomości rolnej zobowiązany jest prowadzić gospodarstwo rolne, jest zmniejszanie areału nieruchomości rolnych niewykorzystywanych rolniczo, co pośrednio przekłada się na sytuację bezpieczeństwa żywnościowego kraju. Ustawowy wymóg prowadzenia gospodarstwa rolnego obliguje bowiem do prowadzenia aktywnej działalności rolnej. Podjęcie takiej działalności wymaga jednak zaangażowania czasowego (praca w gospodarstwie) i finansowego (konieczność ponoszenia nakładów), co pozwala sądzić, że nabywcy nieruchomości skłonni będą prowadzić gospodarstwa rolne w taki sposób, aby zwracały im się bieżące nakłady, a zatem będą wytwarzać produkty rolne, które można zbyć, a nie jedynie uprawiać ziemię. Wytwarzanie produktów rolnych jest natomiast ważne dla zapewnienia bezpieczeństwa żywnościowego.

Przyjęte przez polskiego prawodawcę wymogi skutkują tym, że jeśli osoba będąca rolnikiem indywidualnym zaprzestanie prowadzenia działalności rolniczej, to ze względu na utratę przymiotu osobistego prowadzenia działalności rolniczej traci status rolnika indywidualnego i związane z nim uprawnienie do nabywania nieruchomości rolnych w Polsce. Jest to więc swego rodzaju ,zachęta” do prowadzenia działalności rolniczej przez właścicieli nieruchomości rolnych (albo też „sankcja” za zaprzestanie prowadzenia takiej działalności), co niewątpliwie sprzyja bezpieczeństwu żywnościowemu. Jednocześnie wprowadzone ograniczenia utrudniają nabywanie nieruchomości rolnych przez osoby, których zasadnicza aktywność życiowa i zawodowa ma miejsce poza rolnictwem, a które kupowały ziemię w celach inwestycyjnych lub zakup ten traktowały jako lokatę kapitału, co z kolei stanowi zagrożenie dla bezpieczeństwa żywnościowego. Efektem wprowadzonych w 2016 r. zmian do ustawy o kształtowaniu ustroju rolnego było zmniejszenie liczby transakcji na rynku nieruchomości rolnych i stabilizacja wzrostu cen nieruchomości rolnych ${ }^{66}$.

${ }^{66}$ Uzasadnienie do projektu ustawy o zmianie ustawy o kształtowaniu ustroju rolnego oraz niektórych innych ustaw z 13 marca 2019 r., druk sejmowy nr 3298, s. 3. 
Przyjęte w ustawie instrumenty pozwalają na zapewnienie bezpieczeństwa żywnościowego, a nawet biorąc pod uwagę zachodzące zmiany klimatyczne i ekonomiczne, są konieczne do skutecznego zapewnienia go, a przy tym gwarantują, że ingerencja w prawo własności nie będzie nadmierna $\mathrm{w}$ stosunku do chronionych wprowadzonymi ograniczeniami wartości konstytucyjnych. Nie wpływają natomiast na sposób rolniczego wykorzystania nieruchomości rolnych, a zatem nie stanowią instrumentów bezpośrednio realizujących strategię „Od pola do stołu”. Można jednak stwierdzić, że pośrednio oddziałują na zrównoważenie systemów żywnościowych, gdyż prowadzą do przeciwdziałania nadmiernej koncentracji gruntów. Koncentracja gruntów rolnych oznacza powstawanie bardzo dużych gospodarstw nastawionych na ,przemysłową" produkcję, która negatywnie wpływa na środowisko, i to nie tylko ze względu na stosowanie środków chemicznych (co zapewnia uzyskiwanie wysokich plonów, a przy większej skali produkcji czynniki te mają istotne znaczenie), ale także na stosowanie produkcji monokulturowej na ogromnych powierzchniach gruntów (producenci rolni często bowiem specjalizują się w produkcji określonych produktów rolnych $)^{67}$. Przyjęcie rozwiązań, które uprzywilejowują rolników indywidualnych w nabywaniu nieruchomości rolnych oraz wymuszają prowadzenie działalności rolniczej na nabywanej nieruchomości można więc uznać za pośrednio przyczyniające się do realizacji strategii „Od pola do stołu”. Ustawa o kształtowaniu ustroju rolnego pośrednio wpływa na zrównoważenie systemów żywnościowych. Jednak o ile w kontekście tradycyjnie ujmowanego bezpieczeństwa żywności przyjęte rozwiązania należy uznać za wystarczające, o tyle nie są one wystarczające z punktu widzenia strategii „Od pola do stołu”. Przyjęte rozwiązania nie zawierają bowiem bezpośrednich zachęt do podejmowania działalności rolniczej w sposób bardziej zrównoważony.

${ }^{67}$ Dane statystyczne wskazują, że duże gospodarstwa mają niewielki udział wśród gospodarstw ekologicznych. Przykładowo w 2017 r. największy udział w strukturze gospodarstw ekologicznych miały gospodarstwa o powierzchni od 10 do 20 ha upraw ekologicznych (26,1\%), następnie gospodarstwa o powierzchni od 20 do 50 ha (22\%) oraz gospodarstwa o powierzchni do 5 ha $(20,1 \%)$ i od 5 do 10 ha (19,7\%). Gospodarstwa największe, powyżej 100 ha, stanowiły zaledwie 3,5\%. Podobnie w 2018 r. największy udział w strukturze gospodarstw miały gospodarstwa o powierzchni od 10 do 20 ha upraw ekologicznych $(25,7 \%)$, a najmniejszy - gospodarstwa o powierzchni powyżej 100 ha $(3,7 \%)$. Stwierdzono zmniejszenie udziału gospodarstw o powierzchni od 5 do 10 ha $(18,1 \%)$ i od 10 do 20 ha (25,7\%). Zob. Raport o stanie rolnictwa ekologicznego w Polsce w latach 2017-2018, Inspekcja Jakości Handlowej Artykułów Rolno-Spożywczych, Warszawa 2019, s. 32, https://ijhars.gov.pl/pliki/A-pliki-z-glownego-katalogu/ ethernet/2019/grudzien/SME/Raport\%20ekologiczny_2017_2018_wersja_internet.pdf [dostęp: 15.02.2021]. 


\section{Podsumowanie}

Strategia „Od pola do stołu” ściśle wiąże bezpieczeństwo żywnościowe (tradycyjnie rozumiane jako ogół warunków, jakie muszą być spełnione dla zapewnienia wystarczającej ilości żywności, tj. dostępności i stabilności dostaw żywności odpowiedniej dla aktywnego i zdrowego życia, niezbędnej do wyżywienia ludności świata, danego regionu lub państwa), ze zrównoważonymi systemami żywnościowymi (rozumianymi jako układ lub układy logicznie powiązanych elementów w sferze wytwarzania, przetwarzania produktów rolnych lub żywności, o zrównoważonym charakterze). O bezpieczeństwie żywnościowym można zatem mówić dopiero wtedy, gdy zapewniony jest dostęp do żywności wytwarzanej, przetwarzanej i dystrybuowanej w sposób zrównoważony, tj. tak by ograniczany był negatywny wpływ całego łańcucha żywnościowego na środowisko i klimat, przy jednoczesnym zapewnieniu dostępu do odpowiedniej żywności. Można też stwierdzić, że strategia „Od pola do stołu” wpływa na rozumienie pojęcia „odpowiedniej żywności”, używanego często w kontekście bezpieczeństwa żywnościowego. Żywność odpowiednia to taka, która nie tylko w wystarczającym stopniu zaspokaja potrzeby żywieniowe oraz inne potrzeby człowieka (np. kulturowe, religijne), ale także jest to żywność wytwarzana w sposób zrównoważony.

Zachodzące zmiany klimatyczne oraz zjawiska ekonomiczne na rynku nieruchomości rolnych, jak również kryzysy, w tym kryzys wynikający z pandemii, wpływają na tradycyjnie ujmowane bezpieczeństwo żywnościowe. Stanowią one zarazem wyzwania oznaczające konieczność transformacji obecnie funkcjonujących systemów żywnościowych, tak by stawały się zrównoważone.

Wobec zachodzących zmian gospodarczych, społecznych i klimatycznych oraz ich przewidywanych skutków obowiązkiem państw jest podejmowanie działań zmierzających z jednej strony do zapewnienia bezpieczeństwa żywnościowego nie tylko dla obecnych, ale także przyszłych pokoleń, z drugiej - prowadzących do zmian systemów żywnościowych, aby były one zrównoważone. Jednym $\mathrm{z}$ instrumentów zapewnienia bezpieczeństwa żywnościowego, a zarazem zrównoważenia systemów żywnościowych na etapie wytwarzania żywności pierwotnej jest wprowadzenie regulacji dotyczących obrotu nieruchomościami rolnymi.

Bezpośrednie odniesienie do bezpieczeństwa żywnościowego i do zrównoważonego rolnictwa zawarte w preambule do ustawy o kształtowaniu ustroju rolnego świadczy o tym, że zamiarem ustawodawcy było to, aby ustawa stanowiła jeden $\mathrm{z}$ instrumentów zapewnienia bezpieczeństwa żyw- 
nościowego oraz by przyczyniała się do zrównoważenia systemów żywnościowych.

Dla bezpieczeństwa żywnościowego ma znaczenie zasada nabywania nieruchomości przez rolników indywidualnych i obowiązek prowadzenia gospodarstwa rolnego po nabyciu nieruchomości rolnej. Ograniczenie kręgu osób uprawnionych do nabycia nieruchomości rolnych wpływa na popyt oraz prowadzi do zmniejszenia presji cenowej i ułatwienia dostępu do nieruchomości rolnych rolnikom indywidualnym, prowadzącym gospodarstwa rodzinne, stanowiące w świetle Konstytucji RP podstawę ustroju rolnego w Polsce. Rolnicy indywidualni, jako osoby posiadające odpowiednie kwalifikacje rolnicze i doświadczenie w prowadzeniu gospodarstwa rolnego, są grupą społeczną, dla której dostęp do gruntów rolnych jest warunkiem bezpieczeństwa żywnościowego, bowiem to oni, o ile mają dostęp do odpowiedniej ilości gruntów rolnych, dają gwarancję prowadzenia na tych gruntach działalności rolniczej.

Instrumenty przewidziane $\mathrm{w}$ ustawie o kształtowaniu ustroju rolnego nie mają natomiast bezpośredniego wpływu na rodzaj działalności rolniczej podejmowanej przez rolników indywidualnych, a zatem nie oddziałują na realizację strategii „Od pola do stołu”. Jednak poprzez wprowadzenie instrumentów przeciwdziałających nadmiernej koncentracji gruntów oddziałują pośrednio na zrównoważenie systemów żywnościowych. O ile jednak w kontekście tradycyjnie ujmowanego bezpieczeństwa żywności przyjęte rozwiązania można uznać za wystarczające, o tyle nie są one wystarczające z punktu widzenia strategii „Od pola do stołu”.

Instrumenty prawne służące realizacji tej strategii powinny być uwzględnione we Wspólnej Polityce Rolnej. Zasadne byłoby jednak, aby także na szczeblu krajowym został dokonany przegląd obowiązującej regulacji, w tym dotyczącej obrotu nieruchomościami rolnymi, tak by rozwiązania krajowe w możliwie największym stopniu przyczyniały się do transformacji w kierunku zrównoważonych systemów żywnościowych, tym bardziej że konsumenci zwracają coraz większą uwagę na kwestie środowiskowe, zdrowotne, społeczne i etyczne oraz oczekują dostępu do żywności wytwarzanej przy uwzględnieniu tych wartości.

\section{BIBLIOGRAFIA}

Bukowski Z. (2012), Zrównoważony rozwój w systemie prawa, Toruń.

Campbell B.M. i in. (2016), Reducing risks to food security from climate change, „Global Food Security" 2016, t. 11. 
Frankenberger T.R. (red.) (2003), Household Food Security: Concepts, Indicators, Measurements: A Technical Review, New York - Rome.

Golay Ch., Özden M. (2005), The right to food. A fundamental human right affirmed by the United Nations and recognized in regional treaties and numerous national constitutions. Part of a series of the Human Rights Programme of the Europe-Third World Centre, Geneva.

Kenig-Witkowska M. (1998), Koncepcja sustainable development w prawie międzynarodowym, „Państwo i Prawo” nr 8.

Korzycka M. (2017), Prawa człowieka w prawie żywnościowym, w: M. Korzycka, P. Wojciechowski, System prawa żywnościowego, Warszawa.

Leśkiewicz K. (2012), Bezpieczeństwo żywnościowe i bezpieczeństwo żywności - aspekty prawne, „Przegląd Prawa Rolnego” nr 1(10).

Leśkiewicz K. (2020), Zrównoważone systemy żywnościowe w kontekście reformy Wspólnej Polityki Rolnej - aspekty prawne, „Przegląd Prawa Rolnego” nr 2(27).

Maxwell S., Smith M. (1993), Household food security; a conceptual review, w: S. Maxwell, T. Frankenberger (red.), Household Food Security: Concepts, Indicators, Measurements: A Technical Review, New York - Rome.

Mechlem K. (2004), Food Security and the Right to Food in the Discourse of the United Nation, „European Law Journal” nr 10(5).

Olejarczyk E. (2016), Zasada zrównoważonego rozwoju w systemie prawa polskiego - wybrane zagadnienia, „Przegląd Prawa Ochrony Środowiska” nr 2.

Pastuszko R. (2019), Dostęp do zasobu gruntów rolnych w procesach globalizacji. Zagadnienia prawne, Lublin.

Prokurat S. (2017), Ekonomiczne i prawne aspekty obrotu ziemia w Polsce na tle rynku europejskiego, „Acta Universitatis Wratislaviensis. Ekonomia - Wroclaw Economic Review" nr 23(3).

Rodríguez-Cachón T. (2019), Commission I, National report Spain, European Congress of Agricultural Law - 18-21 September 2019 Poznań (Poland).

Sitek M. (1999), Sustainable development- ciagły czy zrównoważony rozwój?, „Państwo i Prawo" nr 2.

Srogosz T. (2020), Systemy żywnościowe w kontekście Zrównoważonych Celów Rozwoju kilka uwag w czasie pandemii, „Przegląd Prawa Publicznego” nr 6.

\section{FOOD SECURITY AND RESTRICTIONS OF TRADING IN AGRICULTURAL REAL ESTATE IN THE CONTEXT OF THE "FARM TO FORK" STRATEGY}

\section{Summary}

The aim of the considerations was an attempt to outline the mutual relations between restrictions of trading in agricultural real estate introduced by the Act on shaping the agricultural system, food security and sustainable food systems, as well as to verify to what extent Polish regulations concerning the agricultural real estate may be perceived as an instrument to ensure food security and whether the legal solutions adopted are consistent with the "Farm 
to Fork" Strategy. The article presents the basic goals and assumptions of the "Farm to Fork" Strategy, taking into account the European Green Deal, explains the concept of food security, and outlines the basic instruments for restrictions of trading in agricultural real estate introduced by the Act on shaping the agricultural system. In the light of these findings, an assessment of the introduced solutions restricted trading in agricultural real estate in the context of food security and the "Farm to Fork" Strategy was made. The analysis carried out in the article leads to the conclusion that both the principle of purchasing agricultural real estate by individual farmers and the requirement to run a farm on the purchased agricultural real estate contribute to ensuring food security, but they only indirectly affect the implementation of the "Farm to Fork" Strategy.

Keywords: food security, sustainable food systems, agricultural real estate restrictions

\section{LA SICUREZZA ALIMENTARE E LE RESTRIZIONI ALL'ACQUISTO DI TERRENI AGRICOLI NEL CONTESTO DELLA STRATEGIA “DAI CAMPI ALLA TAVOLA"}

\section{Riassunto}

L'articolo si propone di delineare le relazioni che intercorrono tra i vincoli al trasferimento dei terreni agricoli introdotti dalla legge sul regime agrario, la sicurezza alimentare e i sistemi alimentari sostenibili, nonché di verificare in che misura la regolazione del trasferimento dei terreni agricoli di stampo polacco serva da strumento volto a garantire la sicurezza alimentare, e, infine, se le soluzioni ivi proposte si iscrivono nella strategia evocata. L'articolo non solo presenta gli obiettivi di base e i presupposti della strategia "Dai campi alla tavola", incluso il Green Deal europeo, ma spiega anche il concetto di sicurezza alimentare, inoltre delinea gli strumenti di base volti a limitare il trasferimento dei terreni agricoli, introdotti dalla legge sul regime agrario. Successivamente, si procede a valutare le soluzioni introdotte, che, nel contesto della sicurezza alimentare e della strategia "Dai campi alla tavola", portano a limitare il trasferimento in oggetto. L'analisi svolta permette di appurare che il principio di acquisto dei terreni agricoli dai singoli agricoltori, come anche l'obbligo di gestire l'azienda agricola sul terreno acquistato contribuiscono a garantire la sicurezza alimentare e incidono in maniera indiretta sulla strategia "Dai campi alla tavola".

Parole chiave: sicurezza alimentare, sistemi alimentari sostenibili, vincoli al trasferimento dei terreni agricoli 